\title{
Motivação dos Atos Administrativos
}

Por Cláudia Travi Pitta Pinheiro

Data da defesa da dissertação: 20/11/2007

Orientador: Almiro do Couto e Silva

A dissertação investiga os contornos do dever de motivação dos atos administrativos no sistema jurídico brasileiro. O estudo inicia pela análise de seus fundamentos constitucionais, surgimento e desenvolvimento, destacando as diferenças e semelhanças com sua origem e evolução em outros sistemas jurídicos. A perspectiva comparativa está presente também nos capítulos subseqüentes, em que se definem o conteúdo da norma, seu âmbito de aplicação e as conseqüências do descumprimento do dever. O olhar crítico sobre a jurisprudência das cortes brasileiras permeia todos os capítulos do trabalho.

A Banca Examinadora foi composta pelos Professores Doutores: Humberto Bergmann Ávila, Professor da Universidade Federal do Rio Grande do Sul e Doutor em Direito pela Universidade de Munique, LMU, Alemanha; Itiberê de Oliveira Rodrigues, Professor da Universidade Federal de Pelotas e Doutor em Direito pela Universitat Munster (Westfalische-Wilhelms), W.W.U.M., Alemanha; Regina Linden Ruaro, Professora da Pontifícia Universidade Católica do Rio Grande do Sul e Doutora em Direito pela Universidad Complutense de Madrid, U.C.M., Espanha. A referida defesa foi presidida pelo Professor Almiro do Couto e Silva.

\section{A Funcionalidade do Ônus da Prova no Processo Civil Brasileiro}

Por Juliana Leite Ribeiro do Vale

Data da defesa da dissertação: 29/11/2007

Orientador: Carlos Alberto Alvaro de Oliveira

Diante de uma situação de insuficiência probatória, o juiz, impossibilitado de pronunciar o non liquet, deve julgar segundo a regra do ônus da prova. No entanto, em algumas situaçôes, a aplicação da regra prevista no artigo 333 do Código de Processo Civil pode culminar em injustiças. Para evitá-la, a doutrina, a jurisprudência e a legislação apresentam criativas soluções. Na tentativa de sistematizá-las, o trabalho analisa, sob a óptica do juiz, da lei e das partes, alguns fenômenos relacionados ao ônus da prova no Processo Civil brasileiro.

A banca examinadora foi composta pelos Professores Doutores: Danilo Knijnik, Professor da Universidade do Vale do Rio dos Sinos e 
Doutor em Direito pela Universidade de São Paulo; Humberto Theodoro Júnior; Professor Titular da Universidade Federal de Minas Gerais e Doutor em Direito pela mesma instituição; Daniel Francisco Mitidiero, Professor da Universidade Federal do Rio Grande do Sul e Doutor em Direito pela mesma instituição. A referida defesa foi presidida pelo Professor Carlos Alberto Alvaro de Oliveira.

A Divisão Patrimonial na Dissolução da União Estável: Uma Interpretação das Regras de Direito de Família

\section{Por Ana Rispoli D'Azevedo}

Data da defesa da dissertação: 12/12/2007

Orientadora: Claudia Lima Marques

Essa dissertação objetiva analisar a divisão patrimonial, sob o enfoque da união estável, tendo em vista a especificidade do tratamento dado a esta entidade familiar na hipốtese de dissolução. São estudadas as regras que incidem na divisão dos bens, quando da ruptura em vida da união estável, seja consensual ou litigiosa, através da evolução doutrinária e jurisprudencial da matéria. Também se verifica a utilização de regras do direito matrimonial no companheirismo pelos aplicadores da lei e suas conseqüências. Em suma, o tema proposto tem por firn estabelecer a relação entre o desenvolvimento da matéria, ao longo dos anos, pelos Tribunais, pela Doutrina e pelo Legislativo, assim como a determinação consagrada no Código Civil de 2002.

A banca examinadora foi composta pelos Professores: Giselda Maria Fernandes Novaes Hironaka, Professora da Universidade de São Paulo e Doutora em Direito pela mesma instituição; Carlos Silveira Noronha, Professor da Universidade Federal do Rio Grande do Sul e. Doutor em Direito pela Universidade de São Paulo; José Alcebíades de Oliveira Júnior, Professor da Universidade Federal do Rio Grande do Sul e Doutor em Direito pela Universidade Federal de Santa Catarina. A referida defesa foi presidida pela Professora Doutora Claudia Lima Marques.

\section{A Responsabilidade Internacional do Estado por Genocídio} Por Joanessa Tasca Deud Jose

Data da defesa da dissertação: 17/12/2007

Orientadora: Martha Lucía Olivar Jimenez 